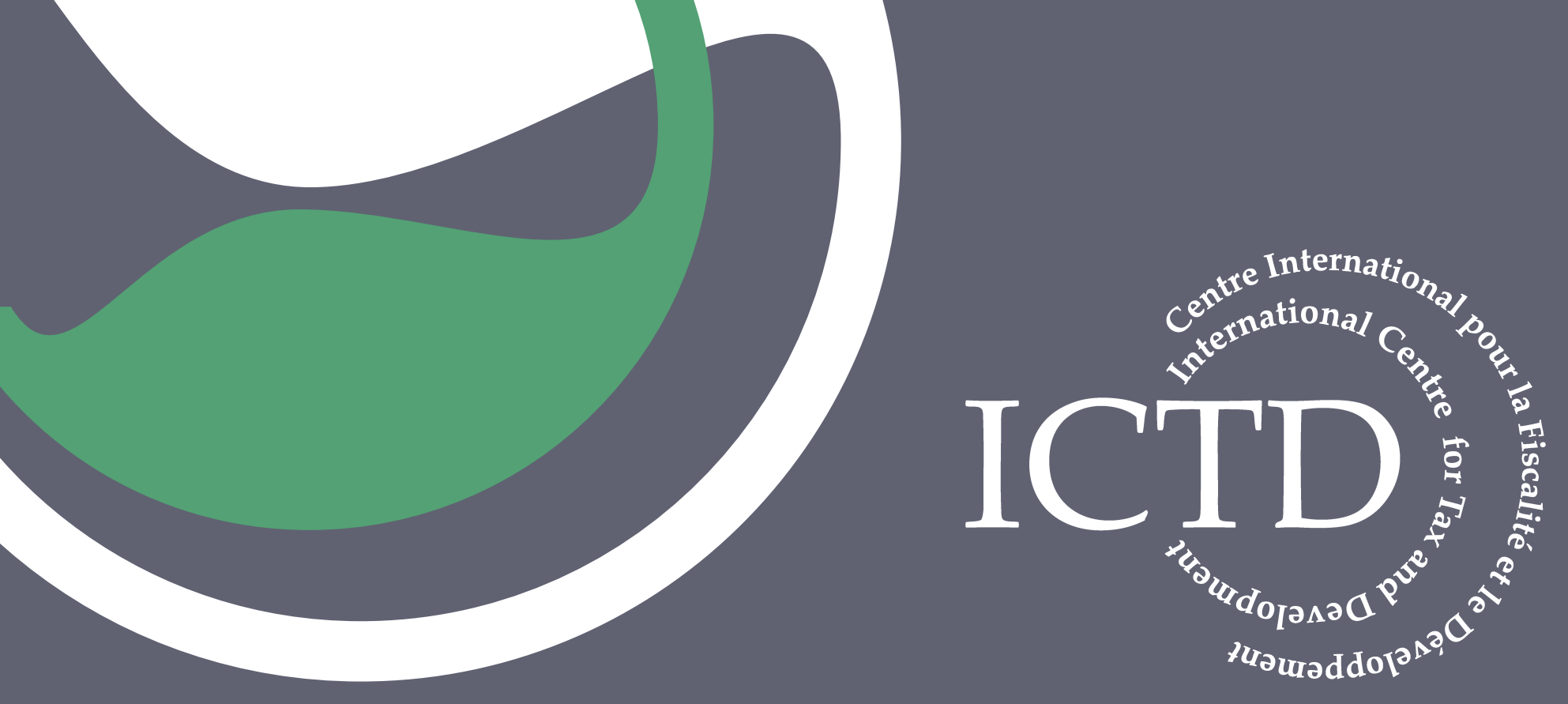

African Tax Administration Paper 17

Taxation of Self-Employed Professionals in Africa: Three Lessons from a Kenyan Case Study

Daisy Ogembo

March 2020 
ICTD African Tax Administration Paper 17

Taxation of Self-Employed Professionals in Africa: Three Lessons from a Kenyan Case Study

Daisy Ogembo

March 2020 
Taxation of Self-Employed Professionals in Africa: Three Lessons from a Kenyan Case Study Daisy Ogembo

ICTD African Tax Administration Paper 17

First published by the Institute of Development Studies in March 2020

(C) Institute of Development Studies 2020

ISBN: 978-1-78118-623-7

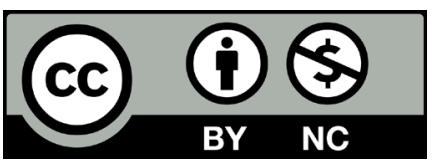

This is an Open Access paper distributed under the terms of the Creative Commons Attribution Non-Commercial 4.0 International license, which permits downloading and sharing provided the original authors and source are credited - but the work is not used for commercial purposes. http://creativecommons.org/licenses/by-nc/4.0/legalcode

Available from:

The International Centre for Tax and Development at the Institute of Development Studies, Brighton BN1 9RE, UK

Tel: +44 (0) 1273606261

Email: info@ictd.ac

Web: www.ictd.ac/publication

IDS is a charitable company limited by guarantee and registered in England

Charity Registration Number 306371

Charitable Company Number 877338 


\title{
Taxation of Self-Employed Professionals in Africa: Three Lessons from a Kenyan Case Study
}

\author{
Daisy Ogembo
}

\section{Summary}

We currently know very little about the taxation of professionals in Africa - scholarly work on this group of taxpayers is scant. The little research that does exist is located within the literature on the taxation of the 'hard-to-tax', a term in tax evasion literature that refers to farmers, small and medium-sized enterprises, and professionals. However, scholarly discourse on the hard-to-tax in low- and middle-income countries, particularly in Africa, has focused primarily on farmers and small and medium-sized enterprises. Professionals are rarely critically considered, despite the acknowledgement in the literature that, considering their potential earnings, the absolute amount involved in evasion by professionals in low- and middle-income countries is probably higher than farmers and small and medium-sized enterprises. This paper begins from the premise that it is sensible to begin to focus more seriously on self-employed professionals in the policy and administrative efforts aimed at increasing tax collection from the informal sector in Africa. Proceeding on that premise, the author provides three lessons that we can learn from a Kenyan case study on taxing selfemployed professionals in Africa.

Keywords: professionals; hard-to-tax; evasion; presumptive tax; trust; compliance; regulators; professional bodies; tax administration; informal sector; Kenya; Africa.

Daisy Ogembo is an Advocate of the High Court of Kenya (non-practising) and holds degrees from University of Oxford (DPhil Law, 2019), University of London (LLM Commercial \& Corporate Law, 2013), and University of Nairobi (LLB, 2006). She is a British Academyfunded Postdoctoral Research Fellow at the Oxford University Law Faculty and a Junior Research Fellow at St Edmund Hall, Oxford. 


\section{Contents}

Summary 3

Acknowledgements 5

$1 \quad$ Introduction $\quad 6$

1.1 Who are the hard-to-tax? 6

What do we know about taxation of self-employed professionals
in Africa?

1.3 Legal framework for taxing professionals in Kenya 8

1.3.1 Income tax 8

1.3.2 Value added tax (VAT) 9

2 Tax attitudes of lawyers and dentists in Kenya 9

2.1 Method 9

$\begin{array}{lll}2.2 & \text { Findings and discussion } & 10\end{array}$

2.2.1 Voluntary or enforced compliance? 10

2.2.2 Partnering with regulators and professional bodies 12

2.2.3 Tax compliance costs, taxpayer literacy and presumptive
taxation

3 Conclusion $\quad 15$

$\begin{array}{ll}\text { References } & 16\end{array}$

Figures

Figure 1

Taxonomy of taxpayers 


\section{Acknowledgements}

Various aspects of this work have been presented at the following conferences and workshops: Addis Ababa (November 2015), Oxford (September 2016), Oxford (June 2018), and Kigali (February 2019). The author is very grateful for comments received from participants in those forums. She is also extremely grateful for financial support from the Oxford University Centre for Business Taxation, the Chartered Institute of Taxation (CIOT), and the Oxford Law Faculty, without which this work would not have been possible. 


\section{Introduction}

This paper addresses the question: what do we know about taxation of self-employed professionals in Africa, and what can tax authorities do to improve their compliance? Scholarly literature on the taxation of professionals has traditionally been located within the broader literature on the (non)-compliance of the hard-to-tax; thus, the first section of this paper briefly introduces the concept of hard-to-tax taxpayers.

\subsection{Who are the hard-to-tax?}

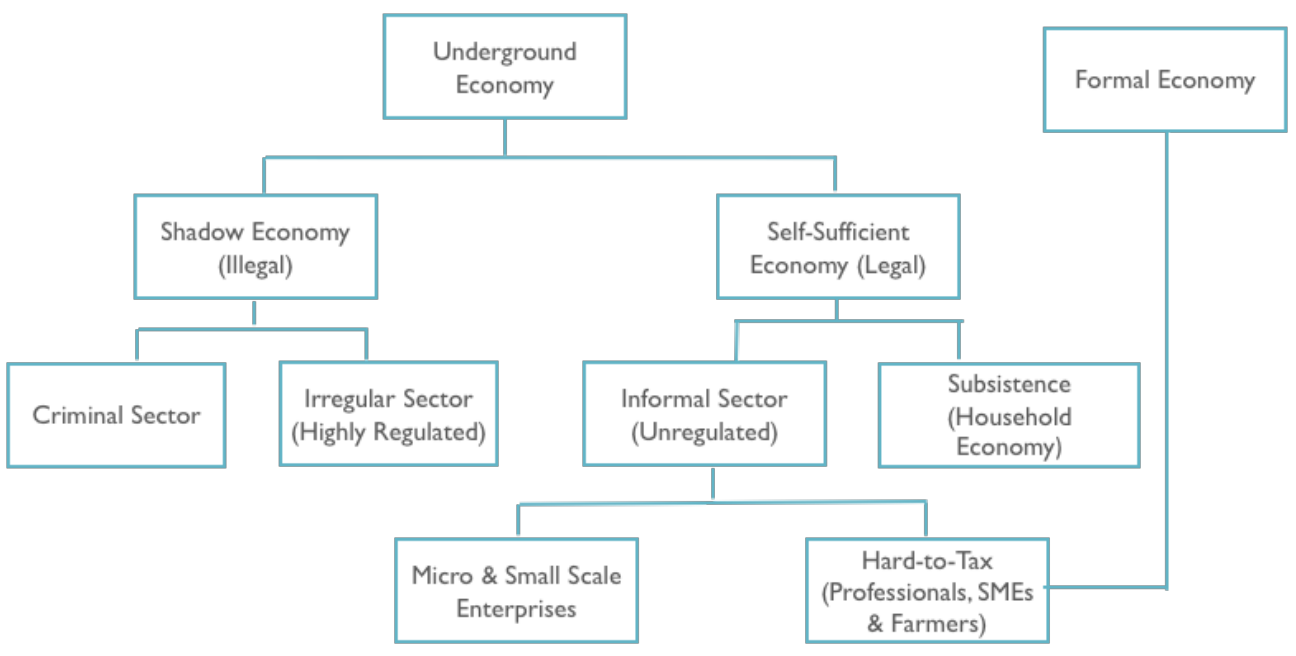

Figure 1 Taxonomy of taxpayers

The term hard-to-tax is not defined in the literature - instead, it is used to describe a group of taxpayers who share specific common characteristics. The consensus in the literature is that the term hard-to-tax encompasses farmers, small and medium-sized firms, and professionals (Casanegra de Jantscher and Tanzi 1987; Musgrave 1990; Tadesse and Taube 1996; Alm et al. 2004).

It is necessary to unpack this description in order to understand why these groups are deemed hard-to-tax, and why other groups are left out of this description. There is no doubt that all taxpayers are hard-to-tax for various reasons; however, scholars writing on the hardto-tax (Alm et al. 2004) take the view that some taxpayers are harder to tax than others because:

1. they do not typically voluntarily register themselves with the revenue authority;

2. they do not typically keep proper books of accounts showing their income and expenditure;

3. they do not typically file their tax returns promptly; and

4. there is a significantly higher rate of tax evasion among these taxpayers.

There is consensus among authors in this field that, while multinational enterprises and businesses engaged in electronic commerce undeniably pose significant challenges for tax authorities, based on the foregoing criteria, they fall outside the category of hard-to-tax taxpayers. ${ }^{1}$

Alm et al. (2004: 14). Undoubtedly, multinational enterprises and digital businesses pose significant challenges for tax authorities globally, as evidenced by the continued work by nations, through the OECD and United Nations, to increase the amount of revenue collected from these taxpayers. The exclusion of multinational enterprises and digital businesses from the hard-to-tax label is solely based on the widely accepted scholarly criteria for identifying taxpayers fitting within 
As suggested in Figure 1, the informality of the hard-to-tax ought to be viewed on a continuum, with hard-to-tax taxpayers coming from both the formal and informal economies (Bird and Wallace 2004; Alm et al. 2004). In the case of professionals, for example, the hardto-tax includes professionals operating in cash in the informal sector and who are genuinely unable to keep proper financial records; it also includes professionals who operate in the formal sector, are capable of keeping and do keep financial records, but will hide their financial affairs from the revenue authority through a mixture of tax evasion and avoidance (Alm et al. 2004).

Professionals and small and medium-sized businesses in the informal economy are typically controlled by owner-managers and a network of close family members, professional associates, friends and employees. These taxpayers, therefore, tend to have weak management systems and financial structures. Additionally, the 'compliance costs or what it takes to meet tax obligations are also higher for small entities especially in relation to the amount of taxes they pay', leading most of them to avoid compliance altogether (Terkper 2003: 213).

A significant number of professionals in developing countries operate mostly in cash-based economies, and either do not keep proper records, or the revenue authority has a difficult time extracting the records from them. When the revenue authority does succeed in doing so, it is difficult to ascertain the accuracy and validity of those records (Musgrave 1990). Further, because the hard-to-tax make up a significant portion of the economy of developing countries, revenue authorities face a large number of individual taxpayers, associated high costs of collection, with the risk of minimal returns. Revenue officials will, more often than not, choose to pursue a small number of large taxpayers and overlook a large number of small taxpayers (Musgrave 1990; Bird and Wallace 2004).

\subsection{What do we know about taxation of self-employed professionals in Africa?}

We currently know very little about the taxation of self-employed professionals in Africa. ${ }^{2}$ In any discussion about taxation of the informal sector or of the hard-to-tax, particularly in the context of low- and middle-income countries, self-employed professionals are an overlooked group. Prior research on the hard-to-tax in low- and middle-income countries has focused almost exclusively on farmers and small and medium-sized enterprises, while largely overlooking tax evasion by professionals. ${ }^{3}$ Thus, professionals do not seem to fit the stereotypical label of informality on the one hand, and are overlooked in compliance strategies for the formal sector on the other.

Farmers have been of interest because many low- and middle-income countries have relied on agriculture and cash crop farming for revenue through international trade. Cash crops, such as coffee, tea, cotton, sugarcane and cocoa, generated significant revenue for these countries in the past. In recent decades, however, this has changed because of various factors including climate change, political instability, corruption, a significant drop in global

\footnotetext{
the label. Looking at the criteria, one could argue that multinational enterprises do not fall within the description of the hard-to-tax because they generally:

i. engage in sophisticated tax avoidance schemes rather than straightforward tax evasion;

ii. employ highly qualified accountants to keep proper and detailed books of accounts and will comply with international accounting standards;

iii. engage the services of highly skilled tax advisors who file timely tax returns;

iv. incorporate and comply with registration requirements, and, in virtually all cases, voluntarily register with the revenue authority.

For emerging research on this topic, see Ogembo (2019a, 2019b).

e.g. see Rajaraman (1995); Terkper (2003); Rajaraman (2005); European Commission (2007); Coolidge and Yilmaz (2016).
} 
prices for these crops, and the failure of low- and middle-income countries to mechanise and utilise technological advancements in agriculture. Other factors include the progressive elimination of duties and tariffs in international trade, and the global movement towards services, e-commerce, technology, and innovation as significant sources of profit. Small and medium-sized enterprises have also occupied much of the research on the hard-to-tax in low- and middle-income countries, because these countries typically have large informal sectors characterised by small-scale traders and cottage industries.

However, we do know that the self-employed have significantly more opportunity for tax evasion than employees whose salaries and wages are subject to employer withholding schemes - this idea is well-documented in tax evasion literature (Jantscher and Tanzi 1987; Torgler 2006; Slemrod 2007; Torgler and Valev 2010; Kleven et al. 2011; Kogler et al. 2015; Cabral et al. 2018; Advani et al. 2017). The position taken in this paper is that self-employed professionals are an important group to study, because the scope for underreporting for highincome earners like doctors, lawyers, contractors and consultants is often significant, particularly when professionals deal with cash transactions - a phenomenon which is not uncommon in African countries (Tadesse and Taube 1996; Keen 2012). According to Keen (2012), these sectors can be responsible for some of the most severe instances of revenue loss and damage to the fairness of the tax system, particularly in developing countries. However, since they are so highly qualified and tightly regulated, it often appears unnatural to refer to professionals as 'informal'. Keen argues that considering their earnings, the absolute amount involved in evasion among professionals is probably higher than any other group. This paper, therefore, begins from the premise that the time has come to devote more academic research, and tax policy and administrative effort, towards professionals, and suggests three ways in which we may consider doing so.

\subsection{Legal framework for taxing professionals in Kenya}

\subsubsection{Income tax}

Under Kenyan law, income tax is chargeable, for each year of income, on the employment income of professionals, whether resident or non-resident, which accrued in or was derived from Kenya. The professionals, like other employees, are also entitled to personal relief currently set at KSh16,896 per month (£130). Section 5 (2) of the Income Tax Act provides that employment income includes 'any wages, salary, leave pay, sick pay, payment in lieu of leave, fees, commission, bonus, gratuity, or subsistence, travelling, entertainment or other allowance received in respect of employment or services rendered', and other benefits and contributions as stated in the Income Tax Act.

Income earned from a self-employed professional vocation ought to be computed separately from any other sources of income of the professional, and such self-employment income is subject to income tax 'charged for a year of income at the individual rates for that year of income'. The individual rates for self-employment income are similar to the rates applied on employment income. Further, unlike their peers in employment, self-employed professionals are entitled to deduct 'expenditure wholly and exclusively incurred' by them in the production of their income, when ascertaining their total income.

Under the Income Tax Act, any resident person whose income from business does not exceed KSh5 million during a year of income may elect to pay income tax under the simplified tax regime known as the presumptive tax regime, rather than the ordinary tax regime. The governing statutory provision expressly bars professional income from eligibility for this presumptive tax regime, even when the professional meets the income criteria. 
Professional fees earned by self-employed professionals are also subject to withholding tax, and '[T]he Commissioner shall not assess any person for any year of income on that portion of income which has been subject to withholding tax which is also a final tax.' Where the professional fee is not a contractual fee, the withholding tax rate is 5 per cent of the gross fee and is payable on fees amounting to KSh24,000 a month and above (approximately £180). Where the professional fee is a contractual fee, the withholding tax rate is 3 per cent of the gross fee and is payable on fees amounting to KSh24,000 a month and above.

\subsubsection{Value added tax (VAT)}

The provision of professional services is a taxable supply. Kenya enacted a new VAT law that met stiff resistance from various quarters in 2013. Within the dental profession, there was disquiet regarding the introduction of VAT on various materials and equipment, on the basis that this move posed a threat to achieving affordable and safe healthcare for all and increased private sector investment in healthcare. The dentists also argued that the additional tax would result in serious economic hardship for self-employed professionals. ${ }^{4}$ In the legal profession, resistance to VAT revolved around the introduction of electronic tax registers, and the mandatory requirement that lawyers who make taxable supplies begin using these devices. The rationale behind the introduction of electronic tax registers was to bring traders who had hitherto been evading VAT into the tax net by electronically tracking their receipts and payments. The legal profession strongly resisted this move, and filed a judicial review application in the High Court challenging the decision; ${ }^{5}$ the Law Society of Kenya lost the case and filed an appeal. ${ }^{6}$ The Society obtained an order of stay pending appeal, and that order remained in place for more than ten years before the appeal was prosecuted and determined in favour of the tax authority. ${ }^{7}$

\section{Tax attitudes of lawyers and dentists in Kenya}

\subsection{Method}

The data for this research was collected through semi-structured interviews with 31 Kenyan respondents - 22 taxpayers, 5 government officials, and 4 experts - in 2015, 2016 and 2018. ${ }^{8}$ To better understand the tax compliance behaviour of self-employed professionals, it was necessary to conduct an in-depth study of taxpayers drawn from one or two professions - dentistry and law were selected for this purpose. It is acknowledged that this is a small number of respondents, from which it is not possible to make generalised conclusions to the whole population (Rogers and Oats 2012). The value of the qualitative data obtained from the small sample size lies in the fact that the author was able to conduct genuinely in-depth interviews, lasting one hour or more, during which the author was able to tease out critical, analytical and in-depth insight.

For a more in-depth discussion on how the imposition of VAT on dental equipment and materials has had an adverse effect on the tax attitudes of dental practitioners in Kenya, see Ogembo (2019a).

Republic v Minister for Finance \& 2 others HC Miscellaneous Civil Application No 644 of 2005 [2006] eKLR.

Law Society of Kenya $v$ Minister for Finance \& 2 others Civil Appeal No 91 of 2006 [2017] eKLR.

See Ogembo (2019a) for a discussion on how the length of the order of stay had unintended consequences for tax compliance behaviour in the legal profession

$8 \quad$ Most of the interviews were conducted face-to-face in Nairobi; 4 were conducted over the telephone. The tax experts interviewed were: 3 senior officers from the Kenya Revenue Authority, 3 senior officers from the National Treasury, 3 tax experts from the private sector, and 1 tax expert from academia. 
In line with the theoretical underpinnings of qualitative research, the goal of this research was not to generalise the findings to the whole population, but to build deep, rich and thick narratives and analysis regarding the perceptions, attitudes and patterns of thought of the respondents. Further, although these narratives and analysis cannot be utilised for statistical generalisation, they have been used for empirical generalisation by 'contributing to and adding to theory' in this field (Rogers and Oats 2012: 31). Besides, towards the end of the interview process with the taxpayers, the author experienced data saturation; the responses mirrored each other to such a significant extent that it is possible that further interviewing within the same professions would not have yielded widely varying data.

Sampling is challenging, particularly where the subject of the research is a sensitive one (Browne 2005). Thus, researchers conducting fieldwork on sensitive topics have often employed individual's social networks through snowball sampling. ${ }^{9}$ The respondents in this research were identified and selected using snowball or referral sampling - each respondent referred the author to acquaintances within their circle who were willing to be interviewed. The first lawyer interviewed was known to the author through professional networks, and that lawyer introduced the author to other self-employed lawyers, and so on. With respect to the dental profession, the author approached a dentist personally known to her, but did not interview that dentist. Instead, this dentist was instrumental in referring the author to other dentists fitting the selection criteria.

This sampling method was advantageous in this context because of the sensitive nature of the research topic. Potential respondents were understandably wary of being interviewed about tax compliance, and a good number went to the extent of inquiring about the author's relationship with the revenue authority. It was much easier to access the population through referrals by their trusted professional colleagues. Their colleagues assured them that the author was 'safe', and that her questions did not pose a risk to them. This approach facilitated easier access, and the author was able to gather even more sensitive data than she set out to collect.

There is a risk that respondents with different traits were not adequately represented and may have presented different and relevant data. However, the counterargument, in this case, is that the legal and dental professions in Kenya are significant, but not overwhelmingly large. The differences in traits and characteristics are not likely to be so large as to render the snowball technique redundant. In addition, the author took steps to vary the characteristics of the respondents interviewed, to ensure that they did not fall into the same category. An attempt was made to ensure that the respondents varied in age, sex and nature or size of their businesses or practice.

\subsection{Findings and discussion}

\subsubsection{Voluntary or enforced compliance?}

The results of this research confirmed that the grand corruption scandals that plague the Kenyan government, coupled with the government's failure to provide services that taxpayers deem to be important (or the failure to provide those services to a satisfactory level), had severe adverse effects on the tax morale of self-employed professionals. This finding is in line with the existing literature on tax morale and corruption. The relationship between corruption and tax morale has been explored in various studies, showing that corruption severely damages the social contract - thereby destroying tax morale and lowering compliance. Corruption may also facilitate tax evasion when taxpayers collude with revenue

Browne (2005) provides an extensive list of such research. 
officers (Torgler 2003; Torgler 2006; Feld and Frey 2007; Fortin et al. 2007; Alm et al. 2016; Balm et al. 2017; Jahnke 2017; Schlenther 2017; Rosid et al. 2018).

Taxpaying was viewed as a pointless exercise, and the respondents believed that their taxes serve no purpose beyond lining the pockets of unscrupulous leaders. The professionals were frustrated by their inability to legitimately hold government accountable for its failures, and viewed tax evasion as the only tool through which they could do so. Further, they believed that the government could not account for the resources it collects, and the cost to the taxpayer is that they have to dig deeper into their pocket to pay for what they argue that the government should provide. Tax officials agreed that impunity at the top has seeped down to the taxpayer and negatively affected compliance. ${ }^{10}$

In dealing with this non-compliance, revenue officials in Kenya view enforcement measures such as audits and surveillance as expensive and time-consuming, and have instead focused on encouraging voluntary compliance. Due to limited enforcement resources, the trend has been to focus more on ensuring compliance by large taxpayers, such as corporate and multinational enterprises, from whom they can collect more tax. ${ }^{11}$ The anticipation is that if the tax authority builds a relationship based on trust with these individual taxpayers, the relationship ought to translate into voluntary compliance and obviate the need to pursue costly and time-consuming mandatory enforcement. This approach is perhaps heavily influenced by contemporary ideas on tax administration advanced by proponents of paradigms such as 'enhanced relationship and cooperative compliance' (OECD 2013), 'responsive regulation' (Braithwaite 2007), and, generally, a more client-based approach to tax administration. It is, however, essential to ask whether these approaches are suitable or effective in all contexts.

While Kenya Revenue Authority certainly has the power to shape its relationship with taxpayers, and even eliminate corruption among its officials in order to cultivate the trust of taxpayers in the authority, it has no control over two very important issues: (i) reducing or eliminating corruption in government, and (ii) proper utilisation of the tax collected to deliver the services that citizens value. These two issues play a critical role in the process of building a relationship of trust, leading to voluntary compliance, between the revenue authority and the taxpayer. Taxpayers do not look at tax collection in isolation - in their assessment they link collection and usage, even though the tax collector has no further role after facilitating the collection and remission of taxes to the executive.

It is challenging to create an environment of trust in the tax authority, and voluntary compliance, when taxpayers believe that taxes are improperly utilised or 'stolen'. ${ }^{12}$ It is also challenging to tackle tax evasion and promote honesty when senior political leaders are perceived to be engaged in fraudulent activity that goes unchecked (Tanzi and Shome 1993). Revenue officers in Kenya agree that corruption in government has severely hampered tax administration. ${ }^{13}$

In an ideal world, the government would tackle corruption aggressively in order to further the revenue collection work of the tax authority. However, revenue authorities must work within the realities that they are presented with - unfortunately, in many low- and middle-income countries, this includes improving compliance despite the corruption problem. Thus, one

\footnotetext{
10 Interview with SC-KRA, Senior Commissioner at Kenya Revenue Authority (Nairobi 10 September 2015); Interview with CM-KRA, Chief Manager at Kenya Revenue Authority (Nairobi 18 May 2016); Interview with M-KRA, Manager at Kenya Revenue Authority (telephone interview, 22 March 2018).

11 Interview with SC-KRA (n 28); Interview with M-KRA (n 28). This trend is now changing as the government faces mounting budget deficits and calls to widen the tax base.

See the discussion on the political economy of taxation in Bird and Zolt (2008: 84-85).

Interview with SC-KRA (n 28); Interview with CM-KRA (n 28); Interview with M-KRA (n 28).
} 
lesson that we can learn from this case study is that severe corruption and poor service delivery by government, particularly in countries where the taxpaying culture is already weak and there is a preponderance of cash transactions, is likely to result in low tax morale that limits the effectiveness of trust, in the revenue authority, in increasing voluntary compliance. Stronger enforcement may be a better tool for increasing compliance levels in these environments.

This proposition has significant implications for tax authorities in low- and middle-income countries - they need to find cost-effective ways of strengthening enforcement among hardto-tax taxpayers. Surveillance and audits are expensive and time-consuming, particularly for resource-limited tax authorities in African countries. Finding and registering the hard-to-tax is an expensive exercise where data is not readily available and curated; tax authority officers may need to go physically from street to street to identify small business owners (Bahl 2004). In the case of self-employed professionals, tax authorities can benefit significantly from taking advantage of various sources of data, including professional associations and regulators, as well as public entities to which these professionals provide their services (Bird and Wallace 2004).

Creative approaches can provide useful supplementary, albeit non-definitive, information, where the collection, curation and dissemination of data is weak - for example, tax authorities can supplement the limited data available with readily observable criteria. The Uganda Revenue Authority has been successful in using lifestyle indicators to identify, and generate a database of, high net worth individuals (Kangave et al. 2018). The value of taxpayers' bank deposits, motor vehicles that they purchase, loans that they can secure for personal use (mortgages) and investment in their firms, have all been successfully utilised in Uganda to identify high net worth individuals who either do not file their returns or underreport their income. Although the publicly available information in newspaper, magazines and social media regarding the lifestyles of professionals cannot be used as conclusive proof of their wealth and income, such knowledge can be used to triangulate more reliable information or prod the taxpayer to produce evidence of their actual income (Kangave et al. 2018).

Research on the taxation of high net worth individuals is a step in the right direction, and there is an urgent need for similar research and thought on cost-effective tax enforcement measures for tax authorities in low- and middle-income countries, since they are often short of the finances and skilled staff required to maintain effective audit rates.

\subsubsection{Partnering with regulators and professional bodies}

Professions, by their very definition, are subject to the oversight function of a body with a monopoly over the rights to admit members to the profession, maintain an up-to-date register of members, and discipline members who are in breach of the profession's code of conduct. The professional bodies may be statutory or set up by the profession (self-regulation). The empirical data collected during this research suggests that professional bodies and regulators in Kenya are not actively involved in tackling tax evasion among members, either by treating tax evasion as serious professional misconduct or ensuring that members are keeping proper financial records and meeting their tax obligations. For example, while the Law Society of Kenya has put in place robust rules governing accounting and professional conduct, these rules are not effectively enforced by the Society.

For instance, despite explicit provisions against undercutting, the lawyers explained that their peers would often give substantial discounts to clients by 'waiving' VAT and taking cash payments to avoid detection or evading income tax to compensate for the fees lost through 
the undercutting. The general feeling seemed to be that everyone was doing it, and one had to join in to remain competitive in the market and earn a living. Most respondents complained about the Law Society of Kenya's failure to act on undercutting, and pointed out that this was one way in which the regulator could play a role in discouraging tax evasion within the profession.

Rules 5 and 7 of the Code of Ethics speak about client-advocate confidentiality and the fiduciary duty over client funds. ${ }^{14}$ In addition, aiding and abetting financial crimes under the guise of these rules is classified as professional misconduct. However, almost all the lawyers confirmed that these rules are routinely breached in practice: lawyers hide their fees in their clients' accounts because they know that these accounts are sacred and protected by law. Efforts by Kenya Revenue Authority to audit such accounts would meet stiff resistance due to the advocate/client confidentiality rules. These breaches amount to professional misconduct, yet it is an area in which the regulator has failed to intervene to ensure compliance. Breaches of the accounting rules and rules against undercutting exacerbate tax evasion by members, but are not adequately addressed by the Society. Further, even though members felt that there was widespread tax evasion within the profession, the issue is not explicitly and adequately addressed in the various professional practice rules.

The failures by other professional associations and regulators were even starker. The Constitution and bylaws of the Architectural Association of Kenya (which incorporates architects, quantity surveyors, town planners, engineers, landscape architects, environmental design consultants and construction project managers) provides, at bylaw 19 and 20 , a list of the principles of professional conduct for the profession, and instances in which a member would be deemed to be guilty of professional misconduct and subject to disciplinary action. These bylaws do not cover the failure to keep proper financial records and comply with tax obligations. Similarly, the Kenya Medical Practitioners and Dentists Board of Kenya does not have specific rules governing financial record-keeping or honesty in tax affairs of its members.

The failure by professionals to keep proper financial records and comply with tax legislation has severe ramifications for the integrity of a profession. Associations or regulators for professions that have demonstrated poor tax compliance should treat the evasion as a 'profession problem' warranting special tax rules and administrative obligations, rather than turn a blind eye or treat the evasion as a private problem in which the body has no interest or role to play. ${ }^{15}$

Thus, a second lesson that we learn from the Kenyan experience is that encouraging compliance by professionals ought to be a joint and multifaceted effort, and the role of regulators and professional associations ought to be enhanced through legislation and other channels of collaboration. Professional bodies and regulators ought to play a much more active role in sanctioning their tax-evading members by treating tax evasion as serious professional misconduct rather than a personal problem not touching on professional ethics. The extent to which this can be done will vary from one context to another, and requires careful contemplation. Should regulators and professional associations 'encourage' compliance or, more drastically, decline to renew practising certificates for members who cannot produce a valid tax compliance certificate from the revenue authority? The latter would be a very effective way of tackling evasion in theory - in reality, it would be

\footnotetext{
14 'Law Society of Kenya Code of Standards of Professional Practice and Ethical Conduct' The Kenya Gazette Special Issue, Gazette Notice No. 5212,

<http://lsk.or.ke/Downloads/Gazette\%20Notice\%20Law\%20Society\%20or\%20Kenya.pdf> accessed 16 July 2018.

15 Email correspondence with Brett Bondfield, Senior Lecturer in Business Law, the University of Sydney Business School, 27 June 2018.
} 
complicated to enforce in some countries where the tax authority's data on these professionals is scant and unreliable at best, and, in the worst-case scenario, absent. In countries plagued by high levels of corruption and poor tax administration records, such a system might also be abused by unscrupulous tax officials or professionals who are intent on destroying their competitors.

\subsubsection{Tax compliance costs, taxpayer literacy and presumptive taxation $^{16}$}

High compliance costs and low taxpayer literacy, particularly among early career professionals running small businesses with modest turnover, emerged as significant barriers to compliance. In many low- and middle-income countries, the policy response to high compliance costs and low taxpayer literacy among hard-to-tax taxpayers is the introduction of a presumptive tax regime (Jantscher and Tanzi 1987). Presumptive taxation 'involves the use of indirect means to ascertain tax liability, which differ from the usual rules based on the taxpayer's accounts' (Thuronyi 2000: 401). In other words, where the revenue authority cannot ascertain a taxpayer's income, or cannot verify the accuracy thereof, presumptive regimes allow them to presume the amount of income based on alternative observable indicators - that is, an alternative base determined by the revenue authority (Bird and Wallace 2004).

However, virtually all countries that operate a presumptive tax system will apply the regime to small and medium-sized enterprises and farmers, but explicitly make professional income ineligible, through the language of the statute. Thus, self-employed professionals are usually unable to take advantage of presumptive tax regimes, even where they meet the other eligibility criteria. There are some exceptions: Greece, India, Costa Rica and Guatemala operate different types of presumptive tax regimes for professionals (Ogembo 2019a).

The opposition to the eligibility of professionals for presumptive tax regimes is ordinarily premised on, inter alia, two main grounds. The first is that professionals are highly educated and regulated, and ought not to be subject to an 'unsophisticated' tax regime. The second is that these regimes are intended to lower the compliance costs faced by small taxpayers, such as small and medium-sized enterprises, and not professionals. However, these presumptions fail to consider the case of professionals who are running small firms, or recent graduates at the beginning of their practice, for whom the typical costs of compliance are as high and prohibitive as they are for other small and medium-sized enterprises, forcing many of them to evade taxes and operate in the informal economy. In any event, the case study data revealed that tax literacy among professionals is not as high as is assumed, and early career professionals are unable to raise the financial resources required to procure professional tax and accounting services (Ogembo 2019b). Thus, those professionals who could not afford professional assistance, and were unable to interpret and fulfil their tax obligations, resorted to filing nil returns.

Therefore, the third lesson that we can learn from this case study is that policymakers ought to re-evaluate the blanket disqualification of professionals for presumptive tax regimes. These regimes, if designed in line with the characteristics of a good tax regime, may be of benefit to low- and middle-income countries where professionals evade taxes because of complexity, high compliance costs, and low levels of financial and tax literacy.

16 For an expanded discussion on this topic, see Ogembo (2019b). 


\section{Conclusion}

Singularly focusing on large taxpayers like multinational or domestic corporations, or easierto-tax taxpayers like employees, while ignoring the hard-to-tax like professionals, amounts to 'implicitly allowing greater departures from the law' by the hard-to-tax, thereby altering the way tax statutes work (Lederman and Sichelman 2013: 1688). Lederman and Sichelman rightly argue that 'changes in agency-level enforcement (not rulemaking) can lead to de facto changes in the law that have the same effect as customisation at the substantive lawmaking level' (Lederman and Sichelman 2013:1687). As African countries continue to make great strides in improving tax compliance and increasing revenue collection, it is imperative that policy and administrative efforts go beyond the 'obvious' sources of revenue, and begin to subject often overlooked taxpayers, like self-employed professionals, to a comprehensive compliance strategy. 


\section{References}

A. Advani, W. Elming and J. Shaw (2017) The Dynamic Effects of Tax Audits, IFS Working Paper W17/24, Institute of Fiscal Studies

J. Alm, J. Martinez-Vazquez and C. McClellan (2016) 'Corruption and Firm Tax Evasion', Journal of Economic Behavior \& Organization 124(C):146-163

and F. Schneider (2004) 'SSizing" the Problem of the Hard-to-Tax', in J. Alm, J. Martinez-Vazquez and S. Wallace (eds), Taxing the Hard-to-Tax: Lessons from Theory and Practice, vol 268, Bingley: Emerald Group Publishing Ltd

R. Bahl (2004) 'Reaching the Hardest to Tax: Consequences and Possibilities', in J. Alm, J. Martinez-Vazquez and S. Wallace (eds), Taxing the Hard-to-Tax: Lessons from Theory and Practice, vol 268, Bingley: Emerald Group Publishing Ltd

A. Baum, S. Gupta, E. Kimani and S. Tapsoba (2017) 'Corruption, Taxes and Compliance', eJournal of Tax Research 15(2): 190-216

R. Bird and S. Wallace (2004) 'Is It Really So Hard to Tax the Hard-to-Tax? The Context and Role of Presumptive Taxes', in J. Alm, J. Martinez-Vazquez and S. Wallace (eds),

Taxing the Hard-to-Tax: Lessons from Theory and Practice, vol 268, Bingley: Emerald Group Publishing Ltd

and E. Zolt (2008) 'Tax Policy in Emerging Countries', Environment and Planning C: Government and Policy 26(73): 84-85

V. Braithwaite (2007) 'Responsive Regulation and Taxation: Introduction', Law \& Policy 29(1): 3-10

K. Browne (2005) 'Snowball Sampling; Using Social Networks to Research NonHeterosexual Women', International Journal of Social Research Methodology 8: 47-60

A. Cabral, C. Kotsogiannis and G. Myles (2018) 'Self-Employment Income Gap in Great Britain: How Much and Who?', CESifo Economic Studies 65(1): 84-107 <https://academic.oup.com/cesifo/advance-article/doi/10.1093/cesifo/ify015/5032456>, accessed 12 October 2018

J. Coolidge and F. Yilmaz (2016) 'Small Business Tax Regimes', Viewpoint no 349, Washington DC: World Bank Group <http://documents.worldbank.org/curated/en/331931468179662817/Small-businesstax-regimes>, accessed 23 May 2018

M. Casanegra de Jantscher and V. Tanzi (1987) Presumptive Income Taxation; Administrative, Efficiency, and Equity Aspects, IMF Working Paper 87/54, International Monetary Fund

European Commission (2007) Simplified Tax Compliance Procedures for SMEs, European Commission Enterprise and Industry Directorate-General 
L. Feld and B. Frey (2007) 'Tax Compliance as the Result of a Psychological Tax Contract: The Role of Incentives and Responsive Regulation', Law \& Policy 29(1): 102-120

B. Fortin, G. Lacroix and M. Villeval (2007) 'Tax evasion and social interactions', Journal of Public Economics 91(11-12): 2089-2112

B. Jahnke (2017) How does petty corruption affect tax morale in sub-Saharan Africa: An empirical analysis, WIDER Working Paper 2017/8

J. Kangave, S. Nakato and P.L. Zzimbe (2018) What Can We Learn from the Uganda Revenue Authority's Approach to Taxing High Net Worth Individuals?, ICTD Working Paper 72, Brighton: Institute of Development Studies

M. Keen (2012) Taxation and Development - Again, IMF Working Paper WP/12/220, International Monetary Fund

H. Kleven, M. Knudsen, C. Kreiner, S. Pedersen and E Saez (2011) 'Unwilling or Unable to Cheat? Evidence from a Tax Audit Experiment in Denmark', Econometrica 79(3): 651692

C. Kogler, S. Muehlbacher and E. Kirchler (2015) 'Testing the "slippery slope framework" among self-employed taxpayers', Economics of Governance 16(2): 125-142

L. Lederman and T. Sichelman (2013) 'Enforcement as Substance in Tax Compliance', Washington and Lee Law Review 70(3): 1679-1749

R. Musgrave (1990) 'Income Taxation of the Hard-to-Tax Groups', in R. Bird and O. Oldman (eds), Taxation in Developing Countries, 4th edn, The John Hopkins University Press

OECD (2013) Co-operative Compliance: A Framework: From Enhanced Relationship to Cooperative Compliance, Paris: OECD Publishing <http://dx.doi.org/10.1787/9789264200852-en>

D. Ogembo (2019a) Taxing the "hard-to-tax" in low and middle-income countries: an examination and Kenyan case study, $\mathrm{PhD}$ thesis, University of Oxford

(2019b) 'Are Presumptive Taxes a Good Option for Taxing Self-employed Professionals in Low and Middle-Income Countries?', Journal of Tax Administration 5(2): 26-57 <http://jota.website/index.php/JoTA/article/view/233>, accessed 25 August 2019

I. Rajaraman (2005) 'Taxing Agriculture in a Developing Country: A Possible Approach', in J. Alm, J. Martinez-Vazquez and S. Wallace (eds), Taxing the Hard-to-Tax: Lessons from Theory and Practice, vol 268, Bingley: Emerald Group Publishing Ltd

(1995) 'Presumptive Direct Taxation: Lessons from Experience in Developing Countries', Economic and Political Weekly 30(18/19): 1103-1113 + 1115-1124

H. Rogers and L. Oats (2012) 'Case Studies', in L. Oats (ed), Taxation: A Fieldwork Research Handbook, Routledge 
A. Rosid, C. Evans and B. Tran-Nam (2018) 'Tax Non-Compliance and Perceptions of Corruption: Policy Implications for Developing Countries', Bulletin of Indonesian Economic Studies 54(1): 25-60

B. Schlenther (2017) 'The impact of corruption on tax revenues, tax compliance and economic development: prevailing trends and mitigation actions in Africa', eJournal of Tax Research 15(2): 217-242

J. Slemrod (2007) 'Cheating Ourselves: The Economics of Tax Evasion', Journal of Economic Perspectives 21(1): 25-48

H. Tadesse and G. Taube (1996) Presumptive Taxation in Sub-Saharan Africa; Experiences and Prospects, IMF Working Paper 96/5, International Monetary Fund

V. Tanzi and P. Shome (1993) 'A Primer on Tax Evasion', IMF Staff Papers 40(4): 807-828

S. Terkper (2003) 'Managing Small and Medium-Size Taxpayers in Developing Economies', Tax Notes International, 13 January 2003

V. Thuronyi (2000) ‘Presumptive Taxation', in V. Thuronyi (ed), Tax Law Design and Drafting, Kluwer Law International

B. Torgler (2006) 'The Importance of faith: Tax morale and religiosity', Journal of Economic Behavior \& Organization 61(1): 81-109

_ (2003) 'Tax Morale, Rule-Governed Behaviour and Trust', Constitutional Political Economy 14(2): 119-140

and N. Valev (2010) 'Gender and Public Attitudes Toward Corruption and Tax Evasion', Contemporary Economic Policy 28(4): 554-568 